\title{
Social Immersion Project for Experiential Learning of Sustainable Farming Practices: A Case Study
}

\author{
Jagdish H Godihal, Professor, Civil Engineering, Presidency University, Bengaluru, Karnataka, India \\ drjagdishgodihal@ presidencyuniversity.in
}

Gopalakrishnan N, Assistant Professor, Civil Engineering, Presidency University, Bengaluru, Karnataka, India gopalakrishnan@presidencyuniversity.in

\begin{abstract}
Social Immersion projects (SIP) extends an excellent opportunity to the undergraduate engineering students to learn the engineering skills through experiential, participative and collaborative learning. This makes them to understand the challenges of real world and the best possible technical solutions to such social issues. It gives students a hands on experience of applying the knowledge of engineering to solve practical problems of society at large. The active participation in SIP inculcates the students with work ethics, and practical insights about environment, energy, economy, Social and safety aspects in Sustainable Development Approach (SDA). Agriculture provides impetus to social and economic growth of any country. However, water is the most important input for agriculture output and its efficiency. During this study, students have visited and interacted with the farmers of the two villages, Kukkanahalli and Puttenahalli near Bengaluru. This has provided them with insights of sustainable farming by observing and experiencing the existing practices on the field and interacting with farmers of all category, small to large holding. Keeping this in view, the students' involvement in such social immersion project creates an experiential learning platform to learn the concepts of sustainable farming.
\end{abstract}

Keywords: Sustainable, Farming, Experiential Learning, Social Immersion Projects (SIP)

\section{INTRODUCTION}

India has been an agricultural country wherein $60-70 \%$ of the country's population depends upon agriculture sector, hence it is need of the hour to create awareness among farmers on better farming practices. The majority of the students those have undertaken this project have come from such family. This background had motivated group of eight civil engineering students to select this topic for social immersion project.
Bengaluru is a metropolitan city surrounded by villages practicing farming on the outskirts of it. The farmers of these villages are economically venerable due to scanty rainfall and inadequate water available for farming. The infusing the sustainable concept approach of environment, energy and economy (1) of organic farming practices to increase the qualitative yield of the crops for improved economy.

Further, the main water source in these areas is underground water which is fast depleting due to rapid urbanization and population growth in and around Bengaluru. The primary aim of this project is to create awareness among farmers about sustainable farming to achieve better qualitative yield, return on investments and ultimately leads to a better quality of life. The motivation factors to undertake this study has been given below:

- To create awareness on better water management and irrigation practices to help farmers to have more crop per drop.

- To educate farmers to implement global best practices in farming enabling them to be user friendly with latest technological advancement. The marketing and inventory storage techniques to improve the sales of their produce at best competitive price.

- To create an interest for wider acceptance among farmers to practice organic farming.

The following objectives were selected for the study:

- To motivate farmers for adoption of improved agricultural practices for enhancement of crop production and productivity. 
- Create specific awareness among the farmers to achieve sustainable agricultural production while maintaining soil health \& safeguarding environment.

- To promote awareness about organic farming.

- To promote Agricultural marketing system among the farmers.

\section{METHODOLOGY}

The most important assignment of this course is the teambased group project which students work for 15 hours for two days in this semester. The project will be having four phases, Initiation, Planning, Execution, and Closure (2). The duration of the project as per the event has been given in table 1 .

Table 1. Duration of Social Immersion Project (SIP)

\begin{tabular}{|l|l|l|}
\hline $\begin{array}{l}\text { Sr. } \\
\text { No }\end{array}$ & Phases of Project & $\begin{array}{l}\text { Duration } \\
\text { (Hours) }\end{array}$ \\
\hline 1 & Pre event (Initiation and Planning) & 02 \\
\hline 2 & Project execution & 10 \\
\hline 3 & Post event (Closure) & 03 \\
\hline
\end{tabular}

\section{Initiation and Planning Phase:}

This phase helps the students to formulate the problem for the social immersion project, it highlights in brief about the Nature and Scope of the project in addition to emphasis on the following points:

- Project Proposal to have the points like, Idea behind this project i.e., why this project has been selected, the goals to be derived, Probable effective time required to carry out this project as per the desired outcome, i.e., duration etc..

- Project Scope (Project location, background, direction and track).

- A hierarchy of deliverables / outcomes, students to devised the set of objectives.

- Work breakdown structure (highlighting of work to be done/doing).

- Responsibility assignment matrix (Roles and Responsibilities aligned to deliverables / outcomes; here who is doing what and to achieve which outcome).

- Tentative project schedule (Important dates, deadlines).

- Gathering of Information, data, evidences etc.,

- Review of current practices to prepare the questionnaire for execution phase of SIP.

\section{Execution Phase}

As per the initial planning the students have visited the identified location for the social immersion project on $12^{\text {th }}$ May 2019 to carry out the project as per the objectives. The villages identified to interact with the farmers have been Kukkanahalli village, Hessarghatta and Puttenahalli village near Nelamangla in Bangalore North District. The location map of these two villages have been given in figure 1 and figure 2 respectively.

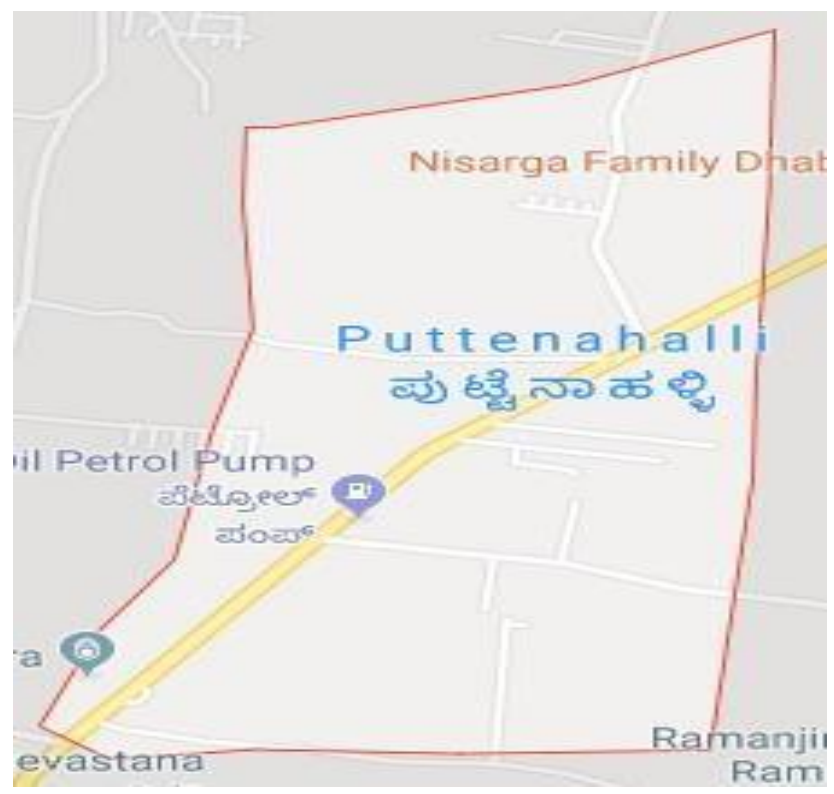

Fig. 1 Location map of Kukkanahalli Village

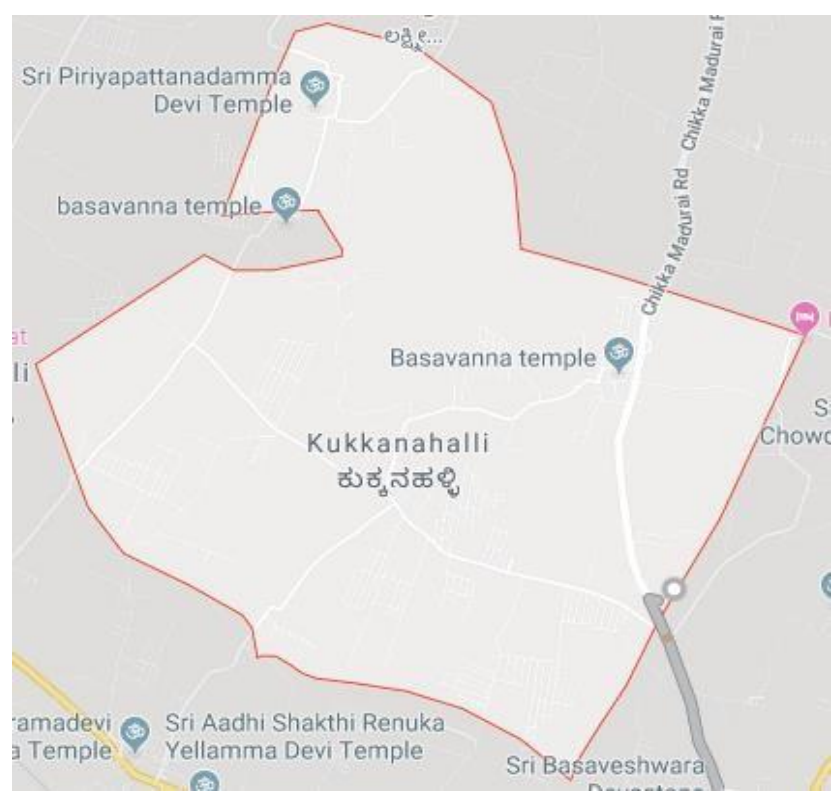

Fig. 2 Location map of Puttenahalli Village

\section{Expected Outcome:}

Each of the objective taken for the study has been mapped to meet the expected outcome as follows (3):

- The farmers understand how to improve their crop 
yield and get more profits.

- Farmers get to know the methods to be adopted by them to ensure that their agricultural practices and production is sustainable safeguards the soil health and the environment.

- This helps to grow the crops without using the synthetic chemicals without any risk of contamination of soil and underground water.

- This helps the farmers to be aware of the existing market prices and the best market (mandi) where they can sell their crop for good price and get good profits.

The questionnaire has prepared keeping in mind the objectives and the targeted outcome achieve the objectives and targeted outcomes to interact with the prospective farmers of both the villages, Kukkanahalli and Puttenahalli. Based on the interaction, discussion had with the farmers on each objectives have been given in the next section of this paper, results and discussion.

\section{RESULTS AND DISCUSSION}

In this section objectives wise interaction with farmers at their respective agricultural land to ascertain and understand the on field farming techniques adopted. This has provided the insights about the existing agriculture practices. The sustainable practices, irrigation practices, soil fertility, cropping pattern, yield, use of advanced agricultural systems, marketing aspects, economical farming etc. The details about these had been given below:

\section{Objective 1: To Motivate the Farmers for adoption of Improved Agriculture Practice for Enhancement of Crop Production and Productivity:}

Poor Water Utilization: Reduced supply, poor quality, and higher water costs are a growing concern. Water shortages affect the ability to provide food for our world's growing population. In a world where two billion people lack access to clean water, efficient and sustainable farming practices are key.

Improve Soil, Increase Crop Yield: To increase crop yield, start from the ground up. Testing soils to determine the cause of declining crop yield is the first step toward finding the source of the issue-whether it's disease, a lack of nutrients, or unproductive soil. Then the soil can be treated with the appropriate organic product needed to solve the problem, without the use of synthetic chemicals harm the crops (Fig. 3) and deteriorate soil environment. Other benefits of biotechnology include: Enhanced plant and beneficial bacteria and fungi growth. Improved soil ecology, recovery, friability, and fertility. Increased microbial diversification, population, and density. Decreased plant stress from environmental conditions. Increased disease resistance and suppression said one of the farmer during interaction.

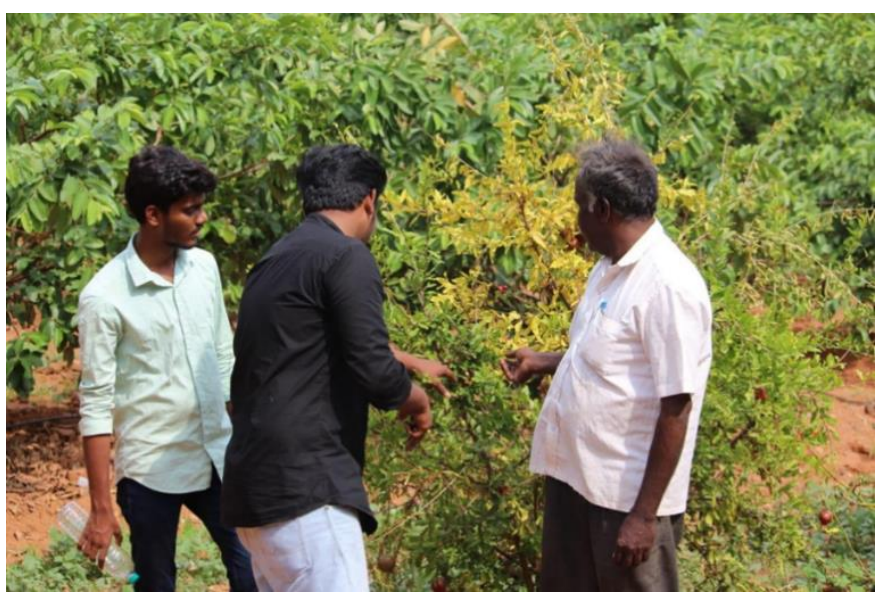

Fig. 3 Farmers explaining about crop health

\section{Increase Crop Yield:}

One of the many innovative products in our product line, blend of green and yellow-green microalgae cells suspended in fresh water and designed to benefit soil structure and plant growth. The organic process to grow and harvest the microalgae is extremely innovative as it utilizes all aspects of plant growth biology in a liquid medium. In addition to improving plant growth, the application of algae has also been shown to suppress soil-borne plant pathogens and repel pests, which eliminate the need for chemical fertilizers and hazardous pesticides [3].

\section{Learning Outcome 1:}

Farmers use phosphate and diammonium phosphate as fertilizers along with NPK (Nitrogen, Phosphate and Potassium). Most of the farmers were not optimistic about organic farming as the return on investment for farming is low as compared to inorganic farming. However, the few farmers are optimistic about the good future for organic farming. Farmers were not positive about the idea of cooperative farming owing to personal difference among framers.

Objective 2: Spreading awareness among the farmers to grow sustainable agricultural production while maintaining soil health.

The sustainable agricultural production can be achieved by adopting the below mentioned practices (4):

- $\quad$ Reducing Tillage

- Avoiding Soil Compaction

- Growing Cover Crops 
- Better Crop Rotation

- Organic Amendments

- Inorganic Amendments

Reducing Tillage: It helps conserve soil moisture and maintain a warmer drier soil environment for seeds.

Avoiding Soil Compaction: Increase the nutrient present in the soil and helps in the improvement of crop production.

Growing Cover Crops: It increases soil susceptibility to erosion because they loosen the soil while leaving less residue behind.

Better Crop Rotation: It helps manage the soil, increase the fertility of the soil and it reduces soil erosion and increase the crop productivity. The farmer explaining the importance of crop rotation has been shown in Fig 4.

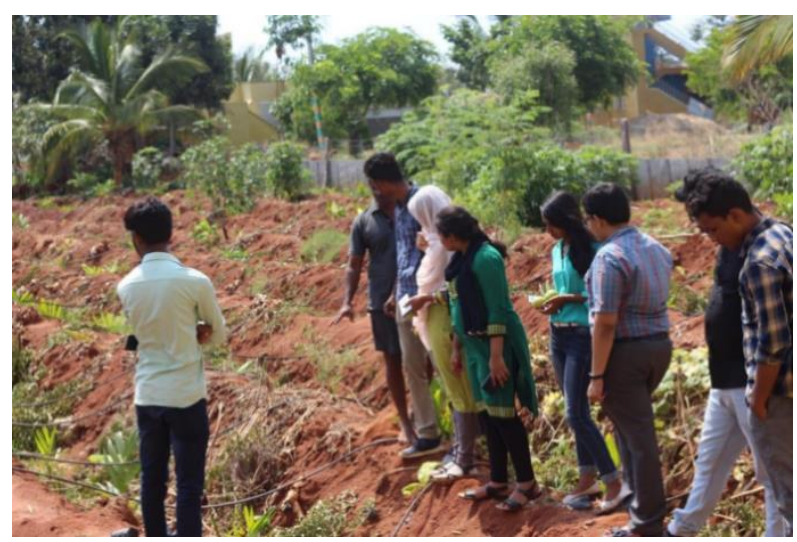

Figure 4. Experiential learning about crop rotation

Organic Amendments: Any material of plants or animals origin is added to the soil to increase its physical properties like water retention and permeability and also its organic content.

Inorganic Amendment: Supports nutrient cycle.

\section{Learning Outcome 2:}

Farmers where quite aware and in fact had more information on all the sustainable agriculture practice listed above. However, from their experience they had certain notions or beliefs which they were unwilling to change particularly on use of organic fertilizer in place of chemical fertilizer and on crop rotation

Objective 3: To create awareness among farmers about Organic Farming

Importance of Organic Farming : Organic farming is a method of crop and livestock production that involves much more than choosing not to use pesticides, fertilizers, genetically modified organisms, antibiotics and growth hormones.

Organic farming promotes the use of crop rotations and cover crops, and encourages balanced host/predator relationships.
Organic residues and nutrients produced on the farm are recycled back to the soil. Cover crops and composted manure are used to maintain soil organic matter and fertility. Preventative insect and disease control methods are practiced, including crop rotation, improved genetics and resistant varieties. Integrated pest and weed management, and soil conservation systems are valuable tools on an organic farm. Organically approved pesticides include "natural" or other pest management products included in the Permitted Substances List (PSL) of the organic standards. The Permitted Substances List identifies substances permitted for use as a pesticides in organic agriculture. All grains, and protein supplements fed to livestock must be organically grown [3]. The advantages of Organic Farming have been summarized as:

- Lower Initial Investment

- High premium for Organic goods.

- Ecological Benefits.

- Healthier Soil.

- Drought Resistance Crops.

- Awesome Marketing Opportunities.

Preparation of Vermi-Compost: The Vermi-compost is a superior bio-organic manure (Fig. 5). The vermi-compost mixes well with the soil there by improves capacity and porosity of soil. It contains NPK and micro nutrients like molybdenum, boron, copper etc. Vermi-compost help soil to increase the water retention capacity and reduces soil erosion [3]. The vermin-compost production is shown in Fig. 6.

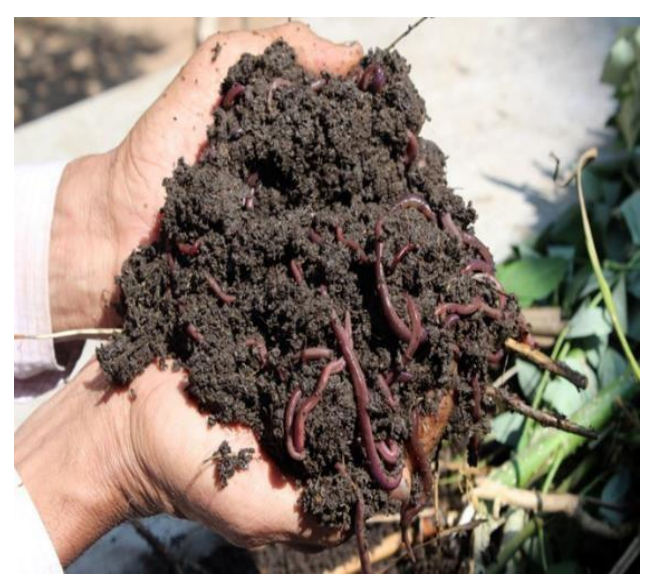

Figure 5. Vermi-compost 


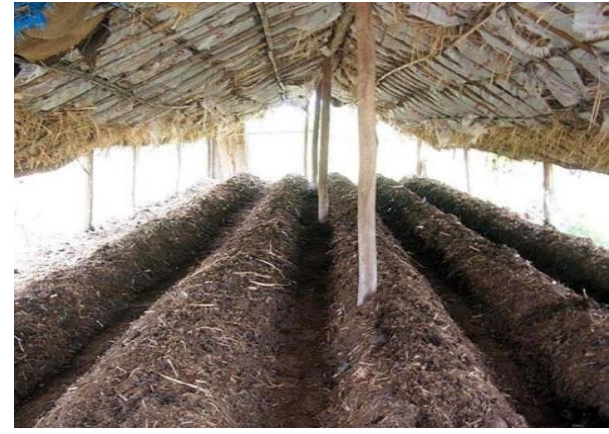

6. Vermi-compost production

\section{Learning Outcome 3:}

Farmers had contrasting opinions on adopting organic farming. The organic manure (Fig.7) has a long lasting impact on a sustainable farming. Few were of the opinion that organic farming could never be economically feasible as they felt the yield would be much lower while others who were practicing organic farming opined that for long term soil health and qualitative crop yield (Fig.8) organic farming is the best option.

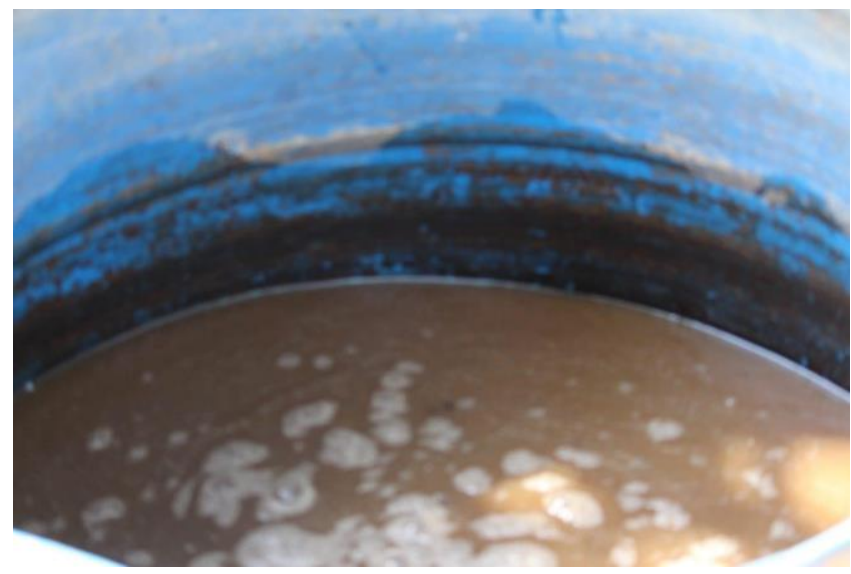

Fig. 7 Organic Manure preparation (Cow dung \& Neem leaves)

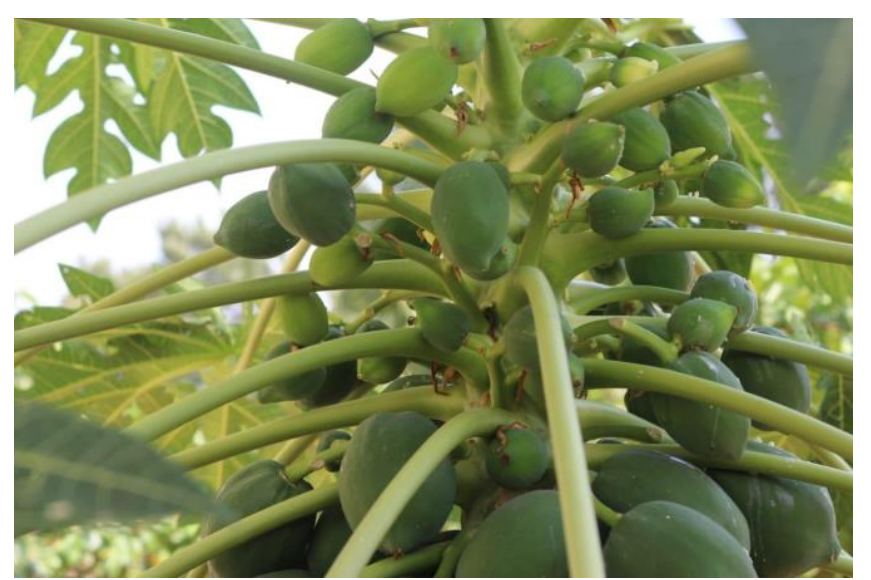

Fig. 8 Yield of Organic farming
Objective 4: To promote Agricultural Marketing System among farmers.

Rashtriya e-Market Services (ReMS) is established as a joint venture of Government of Karnataka (India) and NCDEX spot exchange limited with equal shareholding. It was conceived to blend public interest with the initiative of a private enterprise for establishing, operating, managing a specialized electronic trading platform called Unified Market Platform (UMP) for auctioning of farmer's produce. Department of Agricultural marketing, ReMS and the Markets, work in close coordination to implement the reforms agenda of the State. ReMS has been striving to put in to place the best practices in the agricultural markets like Establishing Assaying facilities, cleaning and grading machinery in markets, capacity building for stakeholders etc.[5]

\section{UMP - Unified Market Platform}

Presently, when farmers bring their produce to the nearest market, at market gate their details are entered on UMP and a unique ID is generated for their lots. Thereafter, these lots are displayed in the market yard for e-tender/ auction as per the instructions given by the farmers. The free of cost assaying facility is also provided at the markets, farmers can avail the facility by allowing the assaying staff to take their produce for testing of commodity on standard quality parameters. In case of e-tender, assaying of lots is performed and the results are displayed on UMP prior to bidding. Local traders can check the commodity physically from the displayed heaps, whereas remote traders can assess the quality of commodity on UMP through published reports. Bidding slots are provided for all lots and traders submit their bids for interested lots within the stipulated time. Post bidding time, tenders are opened and highest bidder is declared as the winner of respective lot. The winning bid and trader's details are sent through SMS's to the farmer's registered mobile number and he can accept or reject the bid price. Post confirmation by farmer, lots are weighed by electronic weighing scales and commodity weighed is uploaded on UMP. The functional modules of UMP are:

Trading Platform: providing multiple price discovery mechanisms.

Material accounting: accounts for all transactions taking place in the market.

Trade fulfilment: completes trade related and all post auction activities.

Fund management: Clearing and settlement of funds.

Document management: Documentation and reports as required

\section{Outcomes and Benefits of UMP:}


- Enhanced transparency through transparent price discovery mechanism: The advanced electronic platform provides efficient price discovery mechanisms, bringing transparency in market operations. It has overcome the odds like local cartelization, opaque bidding process, restricted inter-market trade etc.

healthy competition leading towards better price discovery.

- Real time price information provided by UMP via kiosks, SMSs etc. to farmers, enables them to decide the selling price of produce. This real-time information serves as a bench mark for trade and provides fair chance of bidding for every lot.

- Quality awareness among farmers: To increase the outside traders' participation and to facilitate quality-based bidding, ReMS initiated to bring quality analysis of the commodities. Well-equipped quality assaying labs with automated free assaying machines were established in 40 APMC's [5].

\section{Learning Outcomes 4:}

Well-educated and rich farmers (Fig. 9) were aware of the ReMS service and were availing its benefits.

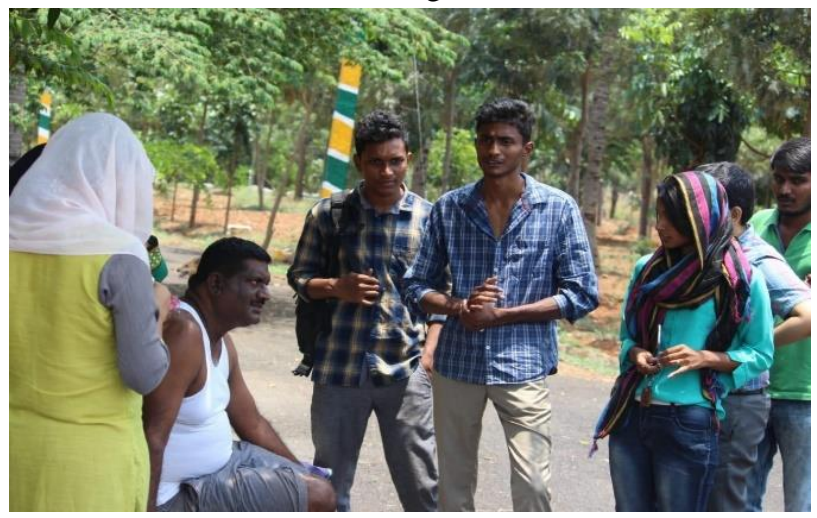

Fig. 9. Farmer sharing information about rich dividends of his Agricultural practices

\section{CONCLUSIONS}

Based on the study carried out the following conclusions have been drawn:

- Effort has been made to create awareness among farmers about latest techniques in agriculture and irrigation practices (i.e., Organic farming, Crop productivity, marketing systems). Farmers contrasting on organic and use of chemicals. The briefing and interactions about merits of organic farming changed their opinion towards organic farming.
- Unified trader license issued to traders facilitates trading across the State and remote bidding encourages outside traders and bulk buyers to trade across all markets as one market in Karnataka. This has put barrier for local cartelization and provided

- Farmers are socially quite aware of latest developments in farming globally. It is only lethargy, pre-conceived notions, false beliefs and impressions and resistance to adopt new methods and process, however, the advancing farm machinery, technology, and emarketing concepts have changed the perceptions of the farmers.

- It's a great experiential learning for the students while interacting with experienced, knowledgeable and highly skilled farmers. It was a good exposure to the real life conditions of the farmers.

\section{ACKNOWLEDGEMENT}

We are thankful to the farmers of Kukkanahalli and Puttenahalli villages near Bengaluru for their support and cooperation during this study. Thankful to the Presidency University, Bengaluru for the constant support and motivation during this work.

\section{REFERENCES}

[1] Kavita J Godihal and Jagdish H Godihal (2019) "Infusing Sustainability Concepts in First Year Engineering Program: A Case Study" The Sixth International Conference on Transformations in Engineering Education (ICTIEE 2019) Jan 7 -8, 2019. IUCEE and Malla Reddy Engineering College, Hyderabad. Telengana, India.

[2] Jagdish H Godihal e-book on "University Learning Course (ULC)" 2019, Civil Engineering Department, Presidency University, Bengaluru.

[3] Nakhat Azeem, Avani.P, Nidhi.S, Balla Gagan Rishith, Sai Kumar Reddy, Ganesh Gaddam, Shaik Abdul Faheem, Pavan Kumar (2019) “Awareness on Good Farming and Irrigation Practices" University Learning Course Report, in partial fulfilment of the requirements for the award of degree of Bachelor of Technology in Civil Engineering. Presidency University, Bengaluru.

[4] S K Garg, "Irrigation Engineering \& Hydraulic Structures" (Water resources Engineering Volume 2), Khanna Publishers, 2017.

[5] http://raitamitra.kar.nic.in/ENG/index.as 